\title{
Gold Uptake by Plants
}

\author{
Christopher WN Anderson, Robert $R$ Brooks and Robert B Stewart \\ Soil and Earth Sciences, Institute of Natural Resources, Massey University, \\ Palmerston North, New Zealand \\ and Robyn Simcock \\ Landcare Research New Zealand Limited, Massey University, \\ Palmerston North, New Zealand
}

Received: 8 December 1998

This review covers three aspects of gold uptake by plants: passive uptake by wild plants under natural conditions; hydroponic studies on plants grown in solutions of gold salts; induced hyperaccumulation of gold by plants grown in auriferous substrates using ammonium thiocyanate as a chelating agent. Using induced hyperaccumulation, it is proposed that it would be technically feasible to grow 'a crop of gold' using Brassica juncea or other plant species.

The uptake of gold by plants has fascinated scientists for well over a century. In 1824 Malte-Brun (1) reported 0.06 to $0.60 \mu \mathrm{g} / \mathrm{g}(\mathrm{ppm})$ gold in wood ash corresponding to $1.2-12 \mathrm{ng} / \mathrm{g}(\mathrm{ppb})$ in the original dry material. Several reviews and original reports have since appeared, such as those of Lungwitz (2), Razin and Rozhkov (3), Jones (4), Shacklette et al (5), Boyle (6), Brooks (7), Dunn (8), Erdman and Olsen (9), and Warren and Delavault (10).

The gold content of wild plants does not usually exceed $10 \mathrm{ng} / \mathrm{g}$ dry weight, even when plants are growing over gold deposits. Reported values higher than this might be due to windborne contamination from the substrate. Plants containing over $1000 \mu \mathrm{g} / \mathrm{g}$ (ppm) nickel or other elements in dry mass are known as hyperaccumulators (11); 100 times the mean metal content of 'normal' plants not growing over mineralization. Using this criterion, Anderson et al (12) have proposed that hyperaccumulation of gold in plants be represented by $1000 \mathrm{ng} / \mathrm{g}(1 \mu \mathrm{g} / \mathrm{g})$ in dry mass. This threshold has not been reached for wild plants growing under natural conditions in spite of a Czech report (13) that cited $610 \mu \mathrm{g} / \mathrm{g}$ gold in the ash of the horsetail Equisetum palustre. Later studies showed that horsetails contain on average only about 1 ng/g dry weight of gold (14) but massive concentrations of arsenic (15). The Czech report may have confused arsenic with gold during the analytical procedure.
The identification of metal hyperaccumulation by plants has resulted in two fields of application. The first of these is phytoremediation (16) in which a plant is grown over polluted soil and harvested after it has accumulated contaminants from the soil. The second application is phytomining $(17,18)$ where a hyperaccumulator is grown to produce a metal crop from soil containing mineralization subeconomic for conventional mining methods. Alternatively, metal contaminants are accumulated by nonhyperaccumulator plants with high biomass, such as maize, by adding a complexing agent to the soil to mobilize an otherwise insoluble contaminant (19). This is known as induced hyperaccumulation.

The literature on gold uptake by plants will be reviewed in three parts: 1 - natural uptake of gold by wild plants, 2 - hydroponic experiments using solutions of gold salts, and 3-induced hyperaccumulation of gold by plants using ammonium thiocyanate.

\section{NATURAL UPTAKE OF GOLD BY WILD PLANTS}

Natural uptake of gold by plants represents by far the greatest proportion of literature citations. In their review of 1985, Erdman and Olsen (9) listed 133 
references of which 50 originated from the former Soviet Union, where plants have been used extensively for biogeochemical prospecting. Of all the elements routinely determined by biogeochemical prospecting, gold gives perhaps the most useful data because the roots of trees and shrubs are able to sample a large volume of soil and thereby avoid the problem of inhomogeneous distribution of the metal. The most useful plants for this type of prospecting include wormwood (Artemisia sp.) found in western USA and southern former Soviet Union, and Douglas fir (Pseudotsuga menziesii) whose trunk wood has been found to contain gold (10) at concentrations to 1 ( $\mu \mathrm{g} / \mathrm{g}$ ash weight $(20 \mathrm{ng} / \mathrm{g}$ in dry matter). Talipov et al (20) analysed numerous plant species and found up to $15 \mathrm{ng} / \mathrm{g}$ (dry mass) in leaves of honeysuckle (Lonicera sp.).

\section{HYDROPONIC EXPERIMENTS ON GOLD UPTAKE BY PLANTS}

Two studies report uptake of gold by plants from hydroponic solutions of gold. Shacklette et al (5) grew unrooted cuttings of Impatiens spp, in solutions of gold chloride, cyanide, bromide, iodide, thiocyanate and thiosulfate for 48 hours. Passive uptake of gold was apparent for all of the solutions used (Table 1). However, these results provided no indication of the expected behaviour of whole plants grown in auriferous soils or mine tailings since passive uptake of metal ions will occur for most plants grown under hydroponic conditions.

Girling and Peterson (21) grew Phacelia sericea

Table 1 Gold Concentrations ( $\mu \mathrm{g} / \mathrm{g}$ dry mass) in Cuttings of Impatiens balsamina and I. holstii Immersed for 48 Hours in Solutions of Gold Salts at Different $p H$ Values

$\begin{array}{lccc}\text { Gold salt } & \mathbf{p H} & \text { I. balsamina } & \text { I. holstii } \\ \text { Cyanide } & 11.0 & 32 & 320 \\ & 7.7 & 32 & 4.2 \\ & 6.5 & 260 & 130 \\ \text { Chloride } & 6.2 & 7.5 & 7.0 \\ \text { Bromide } & 6.2 & 160 & 55 \\ \text { lodide } & 6.0 & 45 & 33 \\ \text { Thiocyanate } & 6.2 & <0.4 & <0.8 \\ \text { Thiosulfate } & 6.2 & 28 & 6.6\end{array}$

(mountain phacelia) and Hordeum vulgare (barley) in various gold solutions. There was a considerable difference between the two species in their ability to absorb gold in a passive fashion - barley contained 0 $1.0 \mu \mathrm{g} / \mathrm{g}$ and Phacelia 6.5-69 $\mu \mathrm{g} / \mathrm{g}$ gold. Phacelia might be able to be used for induced hyperaccumulation of gold.

\section{INDUCED HYPERACCUMULATION OF GOLD BY PLANTS}

Work reported by Anderson et al (12) appears to be the first to describe non-hydroponic studies on the use of plants for induced hyperaccumulation of gold. The form of gold present in an area of mineralization will dictate the concentration of gold that will be introduced into the soil solution after addition of thiocyanate. Anderson et al (12) compared four gold ores and their degree of extractable gold (Table 2). The ore with the greatest relative degree of extractable gold was acidic sulfide mine tailings. These tailings had the lowest total gold but heavily weathered residual gold. By comparison, reduced sulfide ore with the highest total gold content, had very little extractable gold. There has been no success in inducing gold hyperaccumulation from this particular substrate (12). An artificial finely disseminated gold ore was prepared in order to reduce background variability in the glasshouse experiments. The artificial ore was made by dripping a $50 \mu \mathrm{g} / \mathrm{ml}$ gold chloride solution into a finely sieved $(<200 \mu \mathrm{m})$ silica sand. This sand was heated to evaporate the liquid and diluted with fresh sand to produce a $5 \mu \mathrm{g} / \mathrm{g}$ gold substrate. Brassica juncea was chosen for the pot trials because of its high biomass and rapid growth rate.

After approximately 3 weeks growth in the artificial ore, the plants were treated with ammonium thiocyanate at application levels of $0,0.08,0.16,0.32$, and $0.62 \mathrm{~g} / \mathrm{kg}$ dry substrate weight. Seven days later, above-ground parts of each plant were harvested, dried and ashed at $550^{\circ} \mathrm{C}$. The ash was digested in aqua regia before analysis by graphite furnace atomic absorption spectroscopy (GFAAS). Hyperaccumulation of gold was achieved above a thiocyanate treatment level of $0.16 \mathrm{~g} / \mathrm{kg}$ (Figure 1) with a maximum individual value of $57 \mu \mathrm{g} / \mathrm{g}$ gold. The values overall were very variable, probably because of the dichotomy of variable rate of plant death on the one hand and the consequent variation of allowable time for gold uptake on the other. A similar 
Table 2 Thiocyanate-Extractable Gold in Different Types of Mineralization

$\begin{array}{lcccc}\text { Substrate } & \text { Ore geochemistry } & \text { Total Au }(\mu \mathrm{g} / \mathrm{g}) & \begin{array}{c}\text { Extractable } \\ \text { Au (ng) }\end{array} & \begin{array}{c}\text { \% Total Au } \\ \text { extractable* }\end{array} \\ \text { Waihi mine }^{\dagger} & \text { Native Au } & 3.45 & 61.6 & 1.78 \\ \text { Tui mine }^{\dagger} & \text { Acid sulphides } & 0.56 & 114.8 & 22.60 \\ \text { Macraes mine }^{\natural} & \text { Reduced Au ore } & 4.63 & 27.7 & 0.60 \\ \text { Artificial ore }^{\prime} & \text { Disseminated Au } & 5.00 & 460.9 & 9.20\end{array}$

${ }^{*}$ Percentage of total Au extractable in $24 \mathrm{hr}$ in a 1:10 substrate:water ratio by $2 \mathrm{~g} / \mathrm{L}$ ammonium thiocyanate in $24 \mathrm{hr} .{ }^{\dagger} \mathrm{Coromandel}$, New Zealand.

${ }^{\ddagger}$ Te Aroha, New Zealand. 'Macraes Gold Mine, Central Otago, New Zealand. 'Finely disseminated gold prepared by adding gold chloride to quartz sand and heating to convert to native gold.

Table 3 Summary of Data for Various Experiments Involving Induced Hyperaccumulation of Gold by Plants

\begin{tabular}{|c|c|c|c|c|}
\hline Species & Substrate & Added $\mathrm{SCN}^{-}(\mathrm{g} / \mathrm{kg})$ & $\mathbf{N}$ & Au range $(\mu \mathrm{g} / \mathrm{g})^{*}$ \\
\hline Brassica juncea & Waihi ore & 0.50 & 4 & $9.27-19.34$ \\
\hline Chicory & Tui tailings & 0.64 & 5 & $0.07-1.19$ \\
\hline Impatiens sp. & Waihi ore & 0.20 & 1 & 3.09 \\
\hline Arrhenatherum elatius & Waihi ore & 0.50 & 4 & $0.07-1.43$ \\
\hline Brassica juncea & Artificial disseminated Au & 0.64 & 12 & $2.13-57.32$ \\
\hline Brassica juncea & Native gold & 0.25 & 8 & $0.37-6.48$ \\
\hline
\end{tabular}

Au determined by GFAAS on dry mass basis. Values are whole-plant analyses except for B. juncea grown on native gold (leaves only). NB: for further details of the substrates see Table 2.

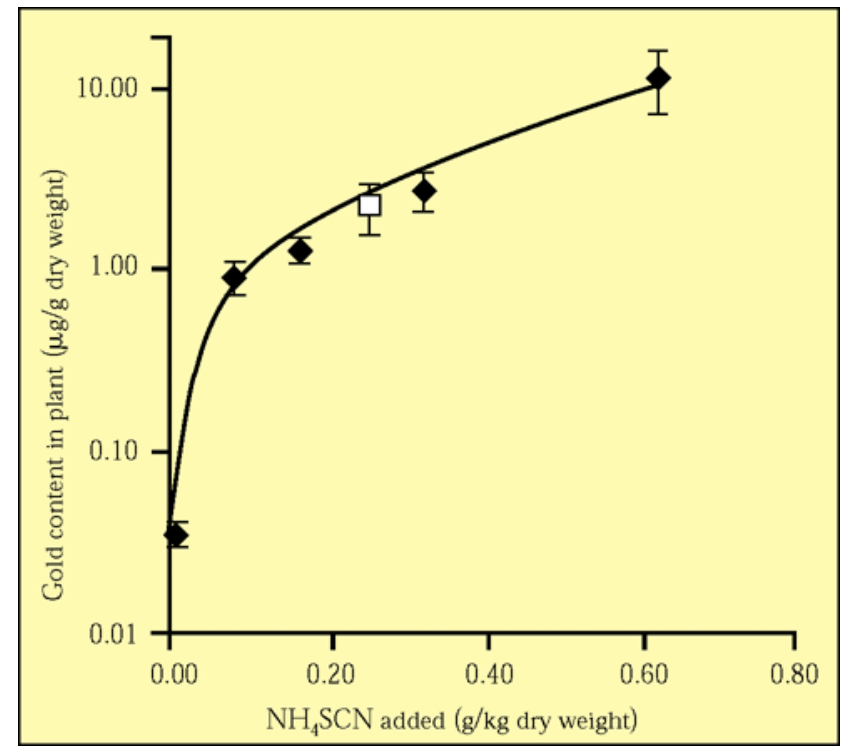

Figure 1 Ammonium thiocyanate-induced uptake of gold by Brassica juncea from finely disseminated (solid diamonds) and native (open square) gold substrates containing $5 \mu \mathrm{g} / \mathrm{g} A u$. experiment grew Brassica juncea in a medium containing $5 \mu \mathrm{g} / \mathrm{g}$ gold prepared from finely powdered elemental gold $(44 \mu \mathrm{m})$ treated with ammonium thiocyanate at an application rate of $0.25 \mathrm{~g} / \mathrm{kg}$ (Figure 1). The average gold in leaves compared well with that of the finely disseminated gold experiment.

Gold uptake data have been gathered for plant species growing in different substrate materials (Table $3)$. The concentration ranges are very variable, reflecting the non-homogeneous natural distribution of metallic gold in some substrates as well as the rate of plant death mentioned previously. Non-homogeneous distribution of gold in geological samples is a problem that has always plagued conventional geochemical sampling.

The feasibility of using induced hyperaccumulation for phytomining for gold has been considered by examining the gross value of a crop of gold and the costs involved in obtaining it using a plant with a biomass of $20 \mathrm{t} /$ ha per annum (Figure 2). At the current world price of $c a$ US $\$ 300 / \mathrm{oz}$, a gold content of around $17 \mu \mathrm{g} / \mathrm{g}$ in the crop would be required to recoup the cost of the thiocyanate. A small 


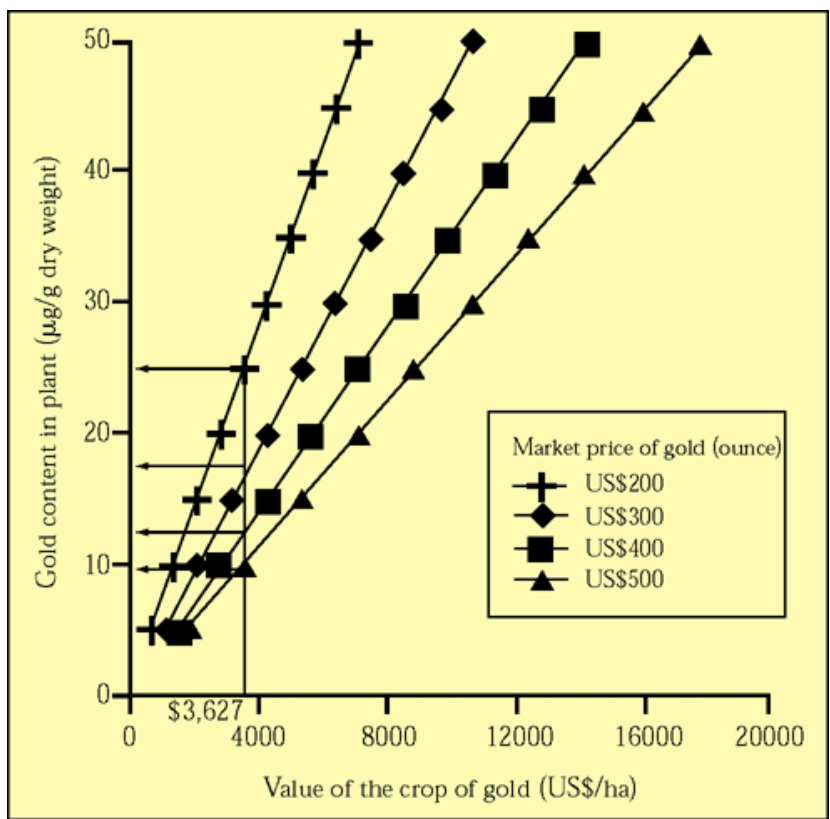

Figure 2 The possible economic value of a phytomined crop of gold as a function of the gold concentration in a plant with a biomass of 20 tonnes/ha. The break-even point to recoup the cost of the reagent is shown by the line cutting the $X$-axis at \$3,627, Profit from selling the energy of combustion of the biomass is not shown in this figure but is of the order of $\$ 250 / \mathrm{ha}$.

percentage of the reported gold values (12) were above this limit.

A further potential dividend in gold phytomining is the sale of energy from combustion of the biomass, as is currently performed by the sugar industry in Queensland. Assuming a biomass of 20 tonnes/ha and that only $25 \%$ of the total energy is recovered (22), the energy yield should be about US $\$ 250 /$ ha. This sum may be reduced somewhat if specialized equipment is needed to ensure complete smoke-free combustion of the biomass. From our own laboratory experiments, it should be possible to remove the very finely divided gold from the plant ash by digestion in warm $2 \mathrm{M}$ hydrochloric acid followed by extraction of the gold into methyl isobutyl ketone (MIBK). Since the distribution coefficient of gold between 2M hydrochloric acid and MIBK is about one million, only a small volume of MIBK would be needed to equilibrate with a much larger volume of acid digestate. The gold can easily be removed from the MIBK by a simple distillation procedure in which the organic solvent can be recovered for re-use.

Phytomining could be used to extract gold from tailings areas that contain gold, but at a level uneconomic for conventional extraction techniques. There is potential here for making a profit from initial stages of a revegetation programme, Phytomining could also be used to extract gold from low-grade ore that many mining companies stockpile in expectation of favourable fluctuations in the value of the metal.

There are environmental concerns related to adding complexing agents or other chemicals to soils or tailings. Thiocyanate is about 500 times less toxic to animals than is cyanide and its biodegradation pathways to ammonia, bicarbonate and sulfate have been well studied (23). Despite its low toxicity relative to cyanide, use of thiocyanate would have to be strictly controlled to prevent leaching of this chemical into water tables and local waterways. For the purpose of the phytomining operation, the leaching of gold solution out of the root zone is certainly not desirable. It has been suggested (24) that it might be possible to use transgenic plants expressing a bacterial thiocyanate degrading system in order to extract gold from auriferous substrates. Such an approach would solve the problem of thiocyanate toxicity to plants and perhaps allow them to extract more gold.

Induced hyperaccumulation of gold, as reported by Anderson et al (12), is the first evidence of significant non-hydroponic gold uptake by any plant. A great deal of research remains to be done before the true place of phytomining will be established, but the findings may have opened up fresh fields of research involving the phytoextraction of other noble metals.

\section{ACKNOWLEDGEMENTS}

We thank AGMARDT of New Zealand for supporting the senior author with an award of a doctoral scholarship. We also thank the Waihi Gold Mine Ltd and Macraes Mining Co Ltd for providing gold ore material.

\section{ABOUT THE AUTHORS}

Chris Anderson is a $\mathrm{PhD}$ researcher in the Soil and Earth Sciences group of the Institute of Natural Sciences at Massey University, New Zealand. Professor Robert R Brooks and Dr Robert B Stewart are in the same group and have been closely involved in this work. Dr Robyn Simcock is a research scientist in Landcare Research, Palmerston North.

Continued on page 58 
(UCC), which is dedicated to the study and development of separation and sensing methods using molecular recognition chemistries, clean technology and miniaturisation. Innovative chemistries are being developed which will replace environmentally unfriendly processes involving solvents or hazardous chemicals. In particular toxic metals are targeted for extraction and analysis, alongside recoverable precious metals (gold, silver) from environmental samples, industrial waste and products.

Stephen John Harris is a senior research associate at $\mathrm{UCC}$, receiving a $\mathrm{BSc}$ (Hons) in chemistry from the University of California (Berkeley) and his $\mathrm{PhD}$ degree from the University of Sussex in the field of organometallic synthesis. He has substantial research and development expertise, gained in industry at Loctite (Ireland) and at Dublin City University and University College Cork. He was visiting professor at the Weizmann Institute of Science in 1991 and has a specialist knowledge of calixarene design and synthesis, recognised in 1987 with Loctite's 'Vernon Kreble Award'. Conor C. McSweeney and Mark P. O'Connell are $\mathrm{PhD}$ postgraduate researchers, while Andrew Walker is a graduate of Queens University Belfast and contributed in organic synthesis through a postdoctoral fellowship at UCC.

\section{REFERENCES}

1 T. Clifford and K. Bartle, Chemistry in Britain, 1993, 499

2 G. Brunner, in 'Proceedings of the 5th Meeting on Supercritical Fluids, Materials and Natural Products Processing, International Society for the Advancement of Supercritical Fluids, 23-25 March 1998 (Nice, France), Vol. 2, pp. 413-424
3 B. Wenclawiak and F.Z. Bichmann, Anal. Chem., 1984, 319, 305

4 C. Fujimoto, H. Yoshida and K. Jinno, J. Microcolumn Separations, 1990, 2, 146

5 Y. Lin, R.D. Brauer, K.E. Laintz and C.M. Wai, Anal. Chem., 1993, 65, 2549

6 (a) Y. Lin and C.M.Wai, Anal. Chem., 1994, 66, 1971 (b) C.M. Wai and S. Wang, J.Chromatography A, 1997, 785, 369

7 C.E. Housecroft, Coord. Chem. Rev, 1992, 115, 117

8 R.V. Parish, Interdicciplinary Science Reviews, 1992, 17, 221

9 F.A. Cotton and G. Wilkinson, Advanced Inorganic Chemistry, A Comprehensive Text', 4th Edition, John Wiley and Sons, New York, 1980, pp. 966-980

10 H. Colley, 'Studies in a Rich Vein', Chemistry in Britain, 1992, 720

11 (a) H. Schmidbaur, Interdisciplinary Science Reviews, 1992, 17 (3), 213

(b) A. Sigel and H. Sigel in 'Handbook on Metals in Clinical and Analytical Chemistry', ed. H.G. Seiler, 1994, p. 388

12 C.K. Chen, T.N. Lung and C.C. Wan, Hydrometallurgy, 1980, 5, 207

13 C.C. Kenna, Gold Bull., 1991, 24 (4), 126

14 D.R. Nagaraj, US Patent 5126038, June 30, 1992, American Cyanamid Company

15 V.V. Yakshin, O.M. Vilkova and N.A. Tsarenko, J. Anal. Chem., 1994, 49, 158

16 S. Fang and L. Fu, Ind. J. Chem., 1994, 33A, 885

17 M. Trom, M. Burgard and A. El-Bachiri, Analysis, 1991, 19,97

18 M. Trom, M. Burgard, M.J.F. Leroy and M. Prevost, J. Membrane Sc, 1988, 38, 295

19 (a) R.L. Bruening, B.J. Tarbet, T.E. Krakowiak, M.L. Bruening, R.M. Izatt and J.S. Bradshaw, Anal. Chem., 1991, 63 (10), 1014

(b) R.L. Bruening, B.J. Tarbet, K.E. Krakowiak, R.M. Izatt and J.S. Bradshaw, J. Heterocyclic Chem, 1990, 27, 347

20 S. Wang, S. Elshani and C.M. Wai, Anal. Chem., 1995, 67, 919

21 E.O. Otu, Separation Science and Technology, 1997, 32 (6), 1107

22 J.D. Glennon, S. Hutchinson, C.C. McSweeney, S.J. Harris and M.A. McKervey, Anal. Chem., 1997, 69 (11), 2207

23 J.D. Glennon, S. Hutchinson, A. Walker, S.J. Harris, and C.C. MCSweeney, J. Chromatography A, 1997, 770, 85

\section{Continued from page 51}

\section{REFERENCES}

1 M. Malte-Brun, 'Universal Geography', Wells and Lilly, 1824

2 E.E. Lungwitz, Min. J. Lond, 1900, 318

3 L.V. Razin and I.S. Rozhkov, 'Geochemistry of Gold in the Weathering Crust and the Biosphere of Kuranakh-type Gold Ore Deposits' (in Russian), Izdat. Nauka, Moscow, 1966

4 R.S. Jones, US. Geol. Surv. Circ, 1970, 625, 1970

5 H.T. Shacklette, H.W. Lakin, A.E. Hubert and G.C. Curtin, U.S. Geol. Surv Bull., 1970, 1314-B. B1

6 R.W. Boyle, Geol. Surv. Can. Bull., 1979, 280, 1

7 R.R. Brooks, J. Geochem. Explor, 1982, 17, 109

8 C.E. Dunn, in 'Noble Metals and Biological Systems', ed. R.R. Brooks, CRC Press, Baton Raton, 1992

9 J.A. Erdman and J.C. Olson, J. Geochem. Explor, 1985, 24, 281

10 H.V. Warren and R.E. Delavault, Geol. Soc. Amer. Bull., 1950, 61, 123

11 R.R. Brooks, J. Lee, R.D. Reeves and J. Jaffré, J. Geochem. Explor, 1977, 7, 49

12 C.W.N. Anderson, R.R. Brooks, R.B. Stewart and R. Simcock, Nature, 1998, 395, 553
13 B. Nemec, L. Babicka and A. Oborsky, Int. Acad. Bohème Sci. Bull., 1936, 37, 1

14 H.L. Cannon, H.T. Shacklette and H. Bastron, U.S. Geol. Surv. Bull, 1968, 1278A, 1

15 R.R.Brooks, J.Holzbecher and D.E. Ryan, J. Geochem. Explor., 1981, 16, 21

16 S.P. McGrath, C.M.D. Sidoli, A.J.M. Baker and R.D. Reeves, in 'Integrated Soil and Sediment Research: a Basis for Proper Protection', ed. J.P. Eijsackers and T. Hamers, Kluwer, Dordrecht, 1993

17 R.L. Chaney, in 'Land Treatment of Hazardous Wastes,' ed. J.F. Parr et al, Noyes Data Corporation, 1983

18 R.R. Brooks, M.F. Chambers, L.J. Nicks and B.H. Robinson, Trends Pl. Sci, 1998, 3, 359

19 M.J. Blaylock et al., Environ. Sci. Technol., 1997, 31, 860

20 R.M.Talipov, V.M. Glushchenko, N.D. Lezhneva and P.Kh.Nishanov, Uzbek. Geol. Zhur., 1974, No.4, 168

21 C.A. Girling and P.J. Peterson, Gold Bull, 1980, 13, 151

22 L.J. Nicks and M.F. Chambers, in 'Plants that Hyperaccumulate Heavy Metals', ed. R.R. Brooks, CAB International, Wallingford, 1988

23 C.H. Hung and S.G. Pavlostathis, Water Res, 1997, 31, 2761

24 C. French, personal communication 